\title{
New NodW- or NifA-Regulated Bradyrhizobium japonicum Genes
}

\author{
Isabelle Caldelari Baumberger, ${ }^{1}$ Nicole Fraefel, ${ }^{1}$ Michael Göttfert, ${ }^{2}$ and Hauke Hennecke ${ }^{1}$ \\ ${ }^{1}$ Institut für Mikrobiologie, Eidgenössische Technische Hochschule, CH-8092 Zürich, Switzerland; ${ }^{2}$ Institut für Genetik, \\ Technische Universität Dresden, D-01062 Dresden, Germany.
}

Submitted 22 July 2002. Accepted 18 December 2002.

\begin{abstract}
A cluster of genes coding for putative plant cell-wall degrading enzymes (i.e., genes for two endoglucanases [gunA and gunA2], one pectinmethylesterase [pme], and one polygalacturonase $[p g l]$ ) was identified by sequence similarities in the symbiotic region of the Bradyrhizobium japonicum chromosome. In addition, a systematic screen of the region revealed several genes potentially transcribed by the $\sigma^{54}$ RNA polymerase and activated by the transcriptional regulator NifA (i.e., genes for proteins with similarity to outer membrane proteins [id117 and id525] and a citrate carrier [id331 or citA] and one open reading frame without similarity to known proteins [id747]). Expression studies using transcriptional lacZ fusions showed that gunA2 and $\mathrm{pgl}$ were strongly induced by the isoflavone genistein in a NodW-dependent manner, suggesting a role of the gene products in early events of the nodulation process; by contrast, gunA and pme expression was very weak in the conditions tested. The gunA2 gene product was purified and was shown to have cellulase activity. $\beta$-Galactosidase activity expressed from transcriptional lacZ fusions to id117, id525, and id747 in the wild type and in nifA and rpoN mutant backgrounds confirmed that their transcription was dependent on NifA and $\sigma^{54}$. Despite the presence of a -24/-12-type promoter and a NifA binding site upstream of citA, no regulation could be demonstrated in this case. Null mutations introduced in gunA, gunA2, pgl, pme, citA, id117, id525, and id747 did not impair the symbiosis with the host plants.
\end{abstract}

Additional keywords: nitrogen fixation, nod genes.

The sequencing of the so-called symbiotic gene region of the Bradyrhizobium japonicum chromosome was completed recently in our laboratories (Göttfert et al. 2001). This chromosomal region of about 400-kb length comprises all of the known nodulation (nod) and nitrogen fixation (nif) genes, which are involved in the nitrogen-fixing interaction between B. japonicum and its host plants (Kündig et al. 1993). Analysis of the nucleotide sequence revealed that $51 \%$ of the open reading frames (ORFs) were homologs to genes in the databases (35\% from rhizobia), $20 \%$ were related to DNA mobilization events, whereas $29 \%$ of the ORFs did not uncover any similarity. Therefore, mutational and gene expression analyses of the whole region might increase our knowledge about genes required at different steps of the symbiotic process. The experiments described in this report are related to two different aspects of this symbiosis: i) the penetration

Corresponding author: H. Hennecke; Telephone: +41-1-6323318; Fax: +41-1-6321382; E-mail: hennecke@ micro.biol.ethz.ch. of the rhizobia into the root hair cell, and ii) the adaptation of the rhizobia to the symbiotic life style, which requires the induction of a number of symbiotic genes in response to the micro-oxic conditions prevailing in the central nodule tissue.

One of the early events in the rhizobial infection of root hairs implies a localized degradation of the root hair cell wall to allow penetration by the rhizobia. This suggests the involvement of plant cell wall-degrading enzymes. The role of such enzymes is well established in pathogenesis. Polygalacturonase (Pgl), pectinmethylesterases (Pme) and pectate lyases, which degrade the pectate network, are glycoside hydrolases or polysaccharide lyases. Cellulases or endoglucanases, which degrade the cellulose network, belong to the hydrolase group. Many organisms secrete multiple isoforms of the same enzymes. Strains of Erwinia spp., the bacterial soft-rot pathogens, produce a set of extracellular enzymes including both pectinolytic enzymes (PehA, PemA, and PemB) and cellulases (CelS, CelV, and CelVI) (Saarilahti et al. 1990a, 1990b, 1992; Mae et al. 1995; Shevchik et al. 1996, 1997). In addition, they also secrete extracellular proteases (Marits et al. 1999). However, none of these enzymes are absolutely required for infection and pathogenicity. Ralstonia solanacearum causes bacterial wilt on an extensive range of host plants, including over 450 plant species. Generally, the bacterium enters host plant roots through wounds, colonizes the root cortex, and invades the xylem vessels. In this process, an endoglucanase (Egl), three polygalacturonases (PehA, PehB, and PehC) and one Pme play important roles but are not absolutely essential for pathogenesis (Roberts et al. 1988; Schell et al. 1988; Tans-Kersten et al. 1998). Thus, plant pathogens possess a multiplicity of plant cell wall-degrading enzymes as virulence factors, but if one considers them individually, they are of limited relevance in the development of a disease.

By analogy with their function in pathogen-plant interactions, pectinolytic and cellulolytic enzymes might play a role in symbiosis. Two highly similar glycanases with cellulolytic activity (PlyA and PlyB) were isolated from Rhizobium leguminosarum bv. viciae (Finnie et al. 1997, 1998; Zorreguieta et al. 2000). However, these enzymes are not required for nodule formation and symbiotic nitrogen fixation in the host plant vetch. The existence of a third glycanase was postulated due to the residual cellulase activity of the double mutant plyA-plyB. Pectinolytic and cellulolytic activities were also detected in cell extracts of $R$. leguminosarum bv. trifolii (Mateos et al. 1992). Recently, the same authors (Mateos et al. 2001) showed that rhizobia penetrate into the legume root hair through a hole created by localized enzymatic degradation of the plant cell wall. Finally, cellulase activity was found in several rhizobial species, including Sinorhizobium meliloti, Mesorhizobium loti, $B$. japonicum, and different $R$. leguminosarum strains 
(Jimenez-Zurdo et al. 1996). Nevertheless, the role of such enzymes in symbiosis remained unclear.

Once bacteria have successfully penetrated into the plant root nodule cells, they divide and differentiate into nitrogenfixing bacteroids. Activation of fix and nif genes in B. japonicum depends on two largely independent regulatory cascades, which both respond to the low-oxygen conditions existing in the host cells (Fischer 1994, 1996). In the FixLJFixK $_{2}$ cascade, the low-oxygen signal is detected and is transduced by the FixLJ two-component regulatory system to the transcriptional regulator FixK $_{2}$. FixK 2 can operate as a repressor or as an activator depending on the target promoter. In the RegSR-NifA cascade, the transcription activator NifA is the oxygen sensor (Fischer 1996). The signal for the RegSR two-component regulatory system is unknown at present (Bauer et al. 1998). NifA activates transcription of nif and fix genes, which are essential for symbiotic nitrogen fixation and comprise the genes for nitrogenase biosynthesis, for synthesis and incorporation of the nitrogenase cofactors, and for regulatory proteins. Transcriptional activation of target genes by NifA involves a specialized RNA polymerase holoenzyme containing the alternative $\sigma$ factor RpoN ( $\sigma 54)$, which enables recognition of characteristic -24/-12-type promoters. NifA usually binds to a conserved upstream activator sequence (UAS) of nif genes.

By sequence analysis, a cluster of genes coding for homologs of secreted plant cell wall-degrading enzymes (i. e., Egl, dipeptidylpeptidase (Dpp), Pgl, and Pme and 32 ORFs possessing -24/-12-type promoters were identified in the sym- biotic region of $B$. japonicum. The purpose of this work was to find out whether such genes play a role in symbiosis.

\section{RESULTS}

Identification of a gene cluster

for plant cell wall-degrading enzymes in B. japonicum.

Sequence analysis of the symbiotic region of $B$. japonicum suggested that id568, id587, id599, id636, and id637 might encode enzymatic functions in the hydrolysis of plant cell wall components. Interestingly, these five ORFs map in relatively close vicinity in the genome (Fig. 1) (Göttfert et al. 2001). The predicted protein product of id568 shows significant similarity (between 43 and 26\%) to cellulases or endoglucanases (GunA) from Streptomyces coelicolor, Aspergillus spp., and Erwinia carotovora (CelS) (Fig. 2). The conserved domain of the glycosyl hydrolase family 12 was detected at the C-terminal end of the protein (Henrissat et al. 1993). Protein Id587 shared a weak similarity $(26 \%)$ with a Dpp of Xanthomonas maltophilia. Similarity was higher between protein Id636 and polygalacturonase (Pgl2) from E. carotovora (36\%) and between Id637 and Pme of Lycopersicon esculentum (30\%). Moreover, Id599 showed 25\% similarity to a methyltransferase of Pyrococcus horikoshi. All these five putative plant cell wall-degrading enzymes were predicted to contain $\mathrm{N}$-terminal signal sequences supporting the hypothesis that these proteins have extracellular functions (Göttfert et al. 2001). The possible function and the regulation of id568 (gunA), id636 (pgl), and id637 (pme) were studied in greater detail with the following experiments.

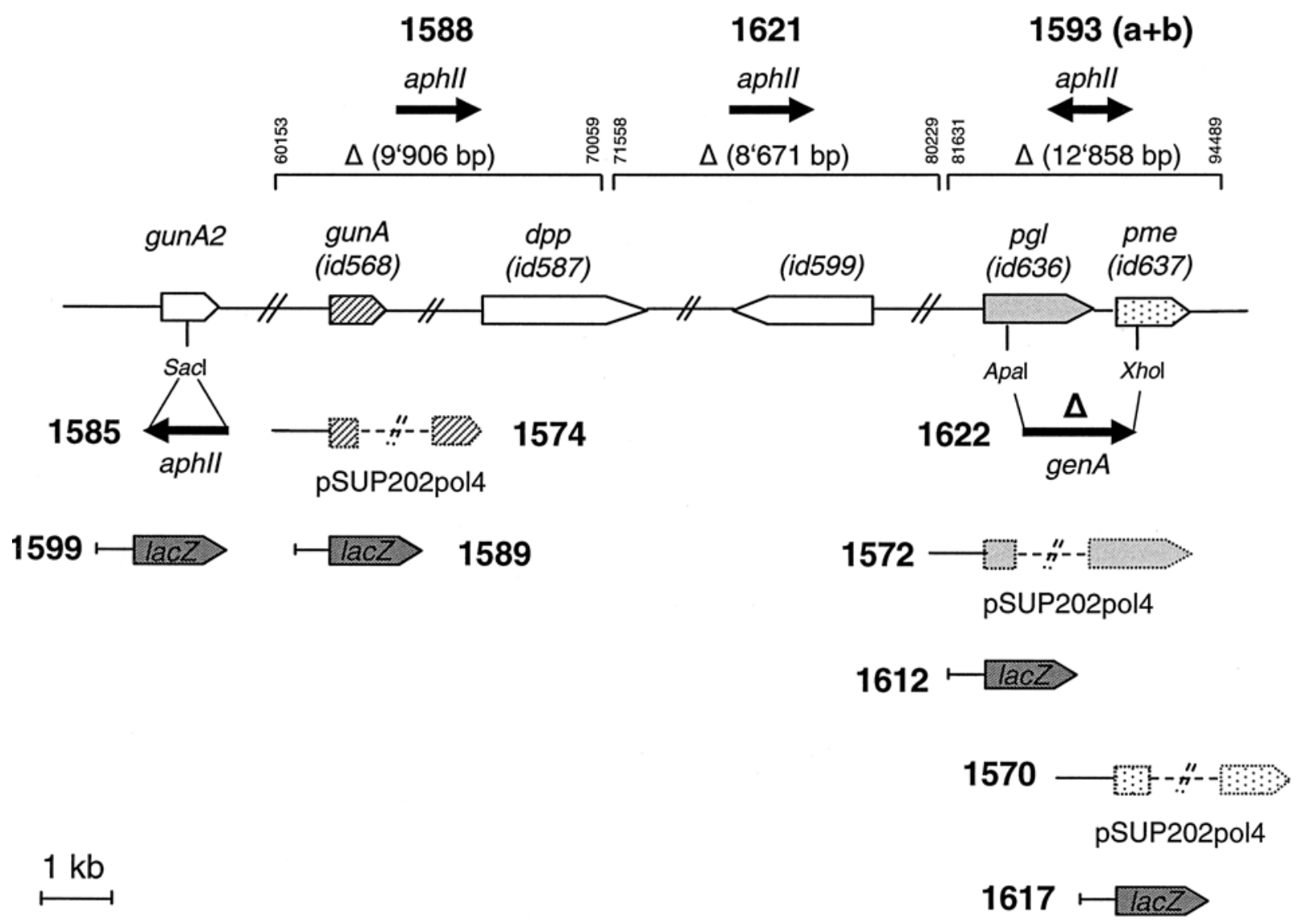

Fig. 1. Physical map of the Bradyrhizobium japonicum gene cluster coding for plant cell wall-degrading enzymes. Nucleotide positions correspond to the sequence deposited in the EMBL database (accession number AF322013). Black arrows refer to the location and orientation of the kanamycin (aphII) or gentamicin $(g e n A)$ resistance gene cassettes that were used for construction of the mutants indicated. The dashed lines represent the positions of the pSUP202pol4 plasmid insertions in the specific genes. The structures of the transcriptional lacZ fusions of gunA2, gunA, pgl, and pme, which were integrated into the chromosome, are depicted. Numbers of the mutant strains are indicated. 
Identification of two $B$. japonicum gunA genes.

When the polymerase chain reaction (PCR)-generated gunA gene (id568) was used to probe a Southern blot of restricted $B$. japonicum genomic DNA under low-stringency conditions, the hybridization signal suggested the presence of a second gunAlike gene, which was cloned and named gunA2 (data not shown). Incidentally, the gunA2 gene was found in a previously sequenced segment downstream of the nod $V W$ genes in the symbiotic region (M. Göttfert, unpublished data). The deduced amino acid sequences of GunA and GunA2 were $73.8 \%$ identical. The N-terminal part of both proteins did not share much similarity (Fig. 2). Indeed, in contrast to GunA, no Nterminal signal sequence was predicted by computer analysis for GunA2. Southern blot experiments using $p g l$ or pme as probes did not show any additional signal, indicating that $p g l$ and pme might be present as a single copy in the B. japonicum genome.

\section{Analysis of gunA, gunA2, pgl, and pme expression with transcriptional $l a c \mathrm{Z}$ fusions.}

To study gunA, gunA2, pgl, and pme expression, transcriptional lac $\mathrm{Z}$ fusions to the four genes were constructed (described below; Fig. 1) and integrated into the chromosome of the B. japonicum wild type. The gunA2-lacZ fusion was also integrated into the chromosomes of the regulatory mutants 613 (nodW mutant) and $\Delta 1267$ (nodD $D_{1+2}$ mutant) (Göttfert et al. 1990a, 1992); for unknown reasons, integration of the pgl-lacZ fusion was successful only in B. japonicum 613 but not in $\Delta 1267$. Cells of all strains were grown in peptone-salts-yeast extract (PSY) medium in the presence of $0.1 \%$ plant cell wall components (carboxymethylcellulose, polygalaturonic acid, or pectin) and different concentrations of genistein $(100 \mathrm{nM}, 500$ $\mathrm{nM}, 1 \mu \mathrm{M}$, and $10 \mu \mathrm{M})$. $\beta$-Galactosidase activity was determined $48 \mathrm{~h}$ after inoculation of the cultures (Fig. 3). The gun $\mathrm{A}$ and pme genes were weakly expressed in any tested conditions. By contrast, gunA2 and $p g l$ were substantially expressed in all conditions and were strongly induced in the presence of $10 \mu \mathrm{M}$ genistein (Fig. 3A and C). In the case of gunA2, this induction was almost completely abolished in the regulatory mutants 613 $\left(\right.$ nod $W$ ) and $\Delta 1267$ (nod $D_{1+2}$ ) (Fig. 3B). Similarly, there was no $p g l$ induction in the regulatory mutant 613 (Fig. 3D). Hence, expression of $g u n A 2$ and $p g l$ is clearly flavonoid-inducible, and transcription of these genes depends on NodW plus NodD for gunA2 and at least on NodW for pgl. The pgl and pme genes are oriented in the same direction and are separated by only $221 \mathrm{bp}$, which might imply that both genes form an operon and, therefore, that expression of pme also depends on the flavonoid-inducible promoter upstream of $p g l$. This assumption was strongly supported by the fact that reverse transcriptionPCR products with correct lengths could be generated from total RNA isolated from B. japonicum wild type in the exponential phase of growth, using four different pairs of primers that allowed amplification of the intergenic region between $p g l$ and pme (data not shown).

\section{Symbiotic properties}

of the gunA, gunA2,pgl and pme mutants.

Mutations in the genes for the putative plant cell walldegrading enzymes were constructed as described below (Fig. 1). The potential roles of gene products Pgl, Pme, and

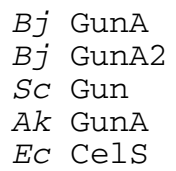

Bj GunA

Bj GunA2

SC Gun

Ak GunA

EC Cels

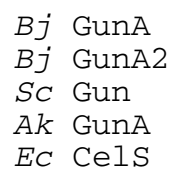

Bj GunA

Bj GunA2

SC Gun

Ak GunA

EC Cels
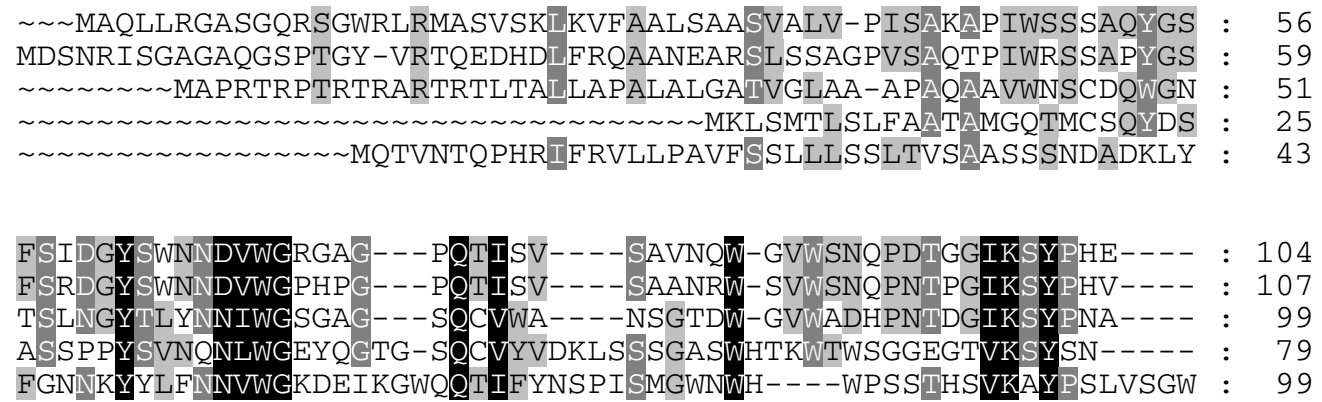
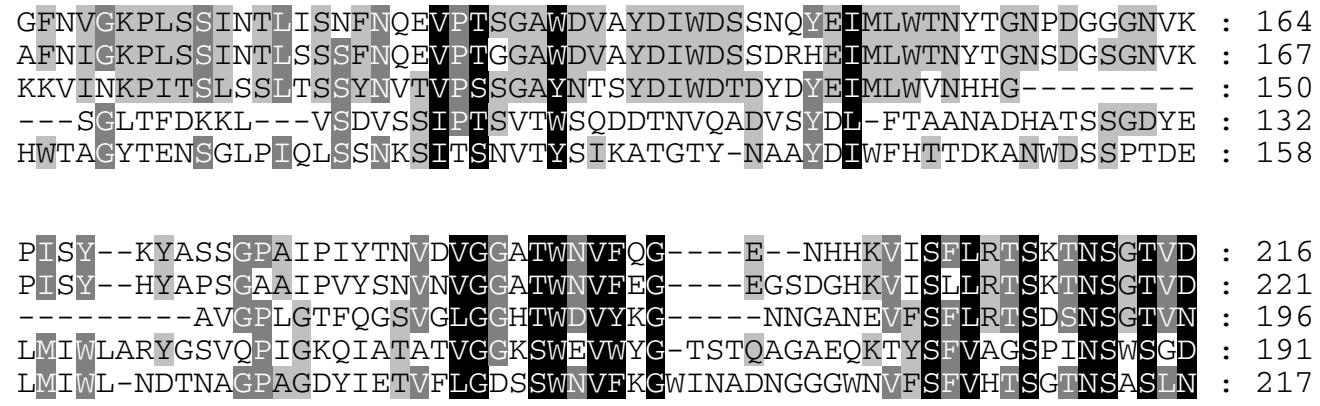

$---E--N H H K V I S$
$---E G S D G H K V I S$
$----N N G A N E V F S$
TSTQAGAEQKTYS
INADNGGGWNVFS

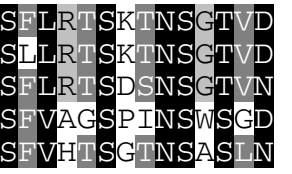

216

221

196

- 191

217

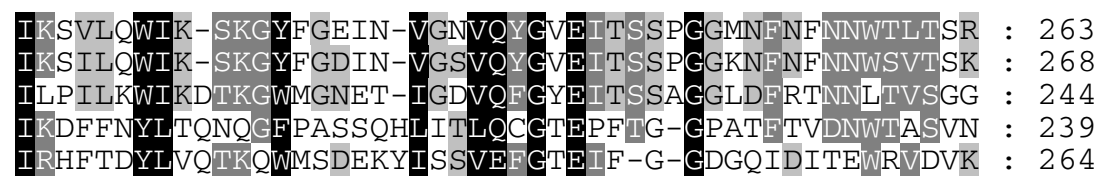

Fig. 2. Amino acid sequence alignment of the Bradyrhizobium japonicum (Bj) GunA and GunA2 proteins with cellulase proteins of Streptomyces coelicolor $(S c)$, Aspergillus kawachii $(A k)$, and Erwinia carotovora $(E c)$. The probable cleavage site of the GunA signal sequence is marked by an arrow. Conserved amino acids are shaded as follows: black for amino acids conserved in all five proteins, dark gray for amino acids conserved in four proteins, and light gray for amino acids conserved in three proteins. 
GunA/GunA2 in symbiotic nitrogen fixation were studied by infection tests with the respective mutant strains, using soybean, cowpea, and mung bean as the host plants. Nodulation and nitrogen fixation activity of the plants were evaluated three weeks after infection. The size, morphology, $\mathrm{N}_{2}$-fixing abilities (Table 1), and the interior color of nodules elicited by all the mutant strains did not differ significantly from those that were formed by the wild-type strain. Thus, the products of $\mathrm{pgl}, \mathrm{pme}$, gunA, and gunA2 are not essential for an effective B. japonicum-host plant symbiosis. In addition, a triple mutant, gunA2pgl-pme (strain 1585+1622), and three large deletion mutants (mutant strains 1588, 1593, and 1621) were constructed (discussed below; Fig. 1) and were tested in plant assays using soybeans. The results in Table 1 show that the nodulation and nitrogen fixation activities of all kinds of mutants did not differ significantly from those of the wild type. Hence, even the combination of several mutations did not impair the ability of the mutant strains to invade host cells.

\section{Cellulase activity in B. japonicum.}

A plate assay was used in an attempt to detect in vivo cellulase activity in the B. japonicum wild type. E. carotovora was included as a positive control. No area of carboxymethyl cellulose (CMC) hydrolysis was observed around B. japonicum colonies as it was seen with $E$. carotovora (data not shown). A CMC-sodium dodecyl sulfate (SDS) polyacrylamide gel elec-

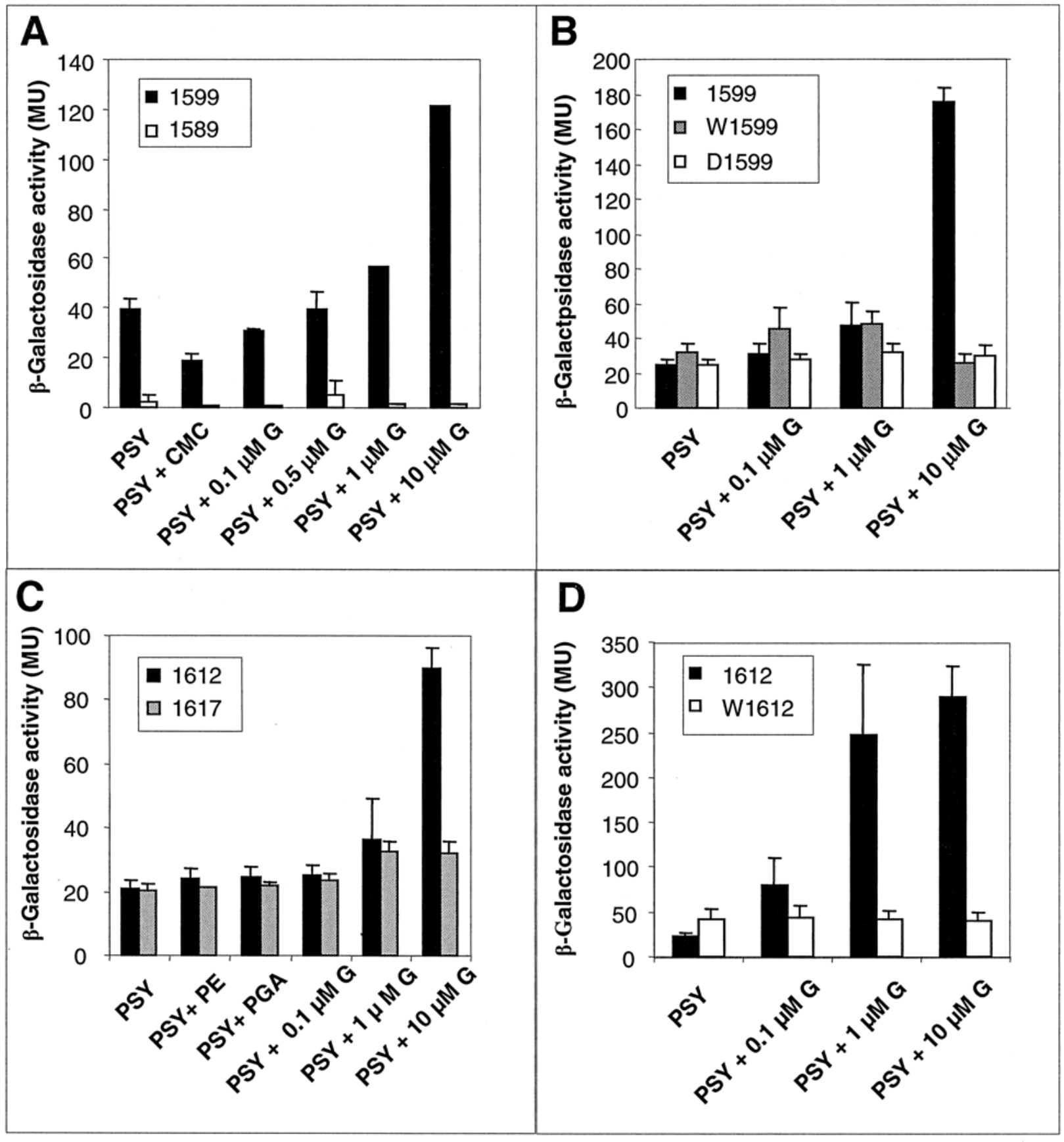

Fig. 3. Expression of chromosomally integrated, transcriptional lacZ fusions. A, gunA-lacZ (1589) and gunA2-lacZ (1599) fusions in Bradyrhizobium japonicum 110spc4; B, gunA2-lacZ in B. japonicum 613 and $\Delta 1267$ (W1599 and D1599); C, pgl-lacZ (1612) and pme-lacZ (1617) fusions in B. japonicum 110spc4; and D, pgl-lacZ in B. japonicum 613 (W1612). Cells were grown under the conditions indicated. Aerobic cultures were grown for 48 $\mathrm{h}$ in peptone-salts-yeast extract (PSY) medium supplemented with carboxy-methylcellulose $(0.1 \% \mathrm{CMC})$, polygalacturonic acid $(0.1 \%$ PGA), pectin $(0.1 \% \mathrm{PE})$, and different concentrations of genistein $(\mathrm{G})$. $\beta$-Galactosidase activities of two cultures were determined in duplicate. 
trophoresis also failed to demonstrate the presence of cellulases in crude-extract protein of B. japonicum cells that had been induced by genistein (data not shown). Both methods were obviously not sensitive enough to detect cellulase activity, and these results are in line with the weak expression observed with the $l a c Z$ fusions. The results are somewhat similar to those obtained previously with $R$. leguminosarum, where it was suggested that glycanases responsible for the degradation of CMC remained cell-bound (Finnie et al. 1998). We therefore changed strategies and tried to overexpress a signal sequenceless GunA variant and the intact GunA2 protein from expression vector $\mathrm{pET} 24 \mathrm{~b}$. The hexahistidine-tagged proteins were purified by affinity chromatography on a Ni-NTA column. On an SDS-polyacrylamide gel, they migrated as bands with apparent molecular masses of 20 to $30 \mathrm{kDa}$ (data not shown), in agreement with the molecular masses calculated from the deduced amino-acid sequences; these are $23.65 \mathrm{kDa}$ for GunA (without signal peptide) and $29.48 \mathrm{kDa}$ for GunA2. Cellulose degradation activity was monitored by measuring the production of reducing sugars, using the sensitive 2,2'-bicinchoninate method (Waffenschmidt et al. 1987). One mg of recombinant GunA2 produced $110.4 \pm 27.0$ pmol glucose per min (average of three experiments). This value compared reasonably well with the activity of commercially available cellulase of Aspergillus niger that produced $199.1 \pm 85.1$ pmol glucose per min per mg of protein. In conclusion, biochemical evidence for the identity of GunA2 as a cellulase was thus obtained. No cellulase activity was observed with recombinant GunA. Whether or not the N-terminal deletion or the histidine tag has possibly affected GunA function was not further investigated.

\section{Identification of genes \\ in the symbiotic region that are transcribed \\ in either a NifA- or RpoN-dependent manner or both.}

For the identification of potential NifA-regulated and RpoNdependent promoters, we searched for the sequences TGT- $\mathrm{N}_{10^{-}}$ ACA (consensus NifA UAS) and TGGCAC-N ${ }_{5}$-TTGCT/A $\left(\sigma^{54}\right.$ consensus promoter), in which $\mathrm{N}_{10}$ and $\mathrm{N}_{5}$ represent stretches of ten or five variable nucleotides (Fischer 1984). A maximal deviation from the consensus sequence at two positions was accepted; however, no deviation at the strictly conserved positions (nucleotides underlined in Fig. 4) in B. japonicum was allowed for the $-24 /-12$ promoter. A systematic screen of the symbiotic region of B. japonicum revealed the presence of over 30 ORFs possessing -24/-12-like promoters, implying their potential transcription by the $\sigma^{54}$ RNA polymerase (Göttfert et al. 2001). In front of many but not all of these promoters, the presence of putative NifA binding sites also indicated possible transcriptional activation by NifA. Figure 4 shows the RpoN and NifA binding sites of those ORFs that were studied here. The proteins encoded by id117 and id525 exhibit amino acid sequence similarity to outer membrane proteins (OMPs), which might have a transport function relevant for the plantbacteria interaction. The product of $i d 331$ (or citA) shares convincing similarity with citrate-proton symport proteins from Salmonella typhimurium, Klebsiella pneumoniae, and a plasmid-mediated citrate transporter from Escherichia coli. The amino acid sequence identity among all these citrate carriers is about $36 \%$. The hydropathy profiles reflect that these carriers, including CitA from B. japonicum, have 12 hydrophobic segments that span the membrane bilayer. No particular similarity of $i d 747$ to other known proteins in the databases was uncovered.

\section{Regulatory and mutational studies on citA, id117, id525, and id747.}

Transcriptional lacZ fusions to citA, id117, id525, and id747 were constructed as described below in order to quantify expression of these genes. The fusions were not only integrated into the chromosome of $B$. japonicum wild type but also into mutants A9 (nifA) and N50-97 $\left(r p o N_{1+2}\right)$. Cells were grown under aerobic or anaerobic conditions, and $\beta$-galactosidase activity was determined (Table 2). Regardless of the genetic background, no significant or only very weak expression of the lac $Z$ fusions was detected when cells had been grown aerobically. By contrast, $\beta$-galactosidase activity derived from the fusions to $i d 117$, id525, and id747, but not from the fusion to citA was strongly induced in the wild-type background under anaerobic conditions. Residual or no activities were measured in the nifA and rpoN $_{1+2}$ mutant strains grown under these conditions. In conclusion, expression studies with id117, id525, and id747 confirmed that their transcription is dependent of NifA and $\sigma^{54}$. However, despite the presence of a -24/-12-type promoter and a potential NifA binding site upstream of citA, neither regulation by NifA nor dependency on $\sigma^{54}$ was demonstrated.

The potential function of citA, id117, id525, and id747 in symbiosis was addressed by testing corresponding mutants (Table 3 ) in a plant assay using soybean as the host plant. The mutants showed a wild-type phenotype with regard to nodule number, size, and morphology of nodules and acetylene reduction activity within the root nodules (Table 1).

Table 1. Symbiotic properties of Bradyrhizobium japonicum wild type and mutants

\begin{tabular}{|c|c|c|c|c|}
\hline \multirow[b]{2}{*}{ Strain } & \multirow[b]{2}{*}{ Nodulation } & \multicolumn{3}{|c|}{$\mathrm{N}_{2}$ fixation (\% of wild type $)^{\mathrm{a}}$} \\
\hline & & Soybean & Mung bean & Cowpea \\
\hline $110 s p c 4$ & + & $100 \pm 26$ & $100 \pm 23$ & $100 \pm 21$ \\
\hline 1570 & + & $83 \pm 30$ & $109 \pm 37$ & $85 \pm 14$ \\
\hline 1572 & + & $105 \pm 34$ & $95 \pm 29$ & $115 \pm 58$ \\
\hline 1574 & + & $134 \pm 23$ & $105 \pm 22$ & $95 \pm 26$ \\
\hline 1585 & + & $129 \pm 28$ & $96 \pm 15$ & $98 \pm 17$ \\
\hline $1585+1574$ & + & $92 \pm 29$ & $108 \pm 19$ & $91 \pm 20$ \\
\hline $1585+1622$ & + & $95 \pm 23$ & ND & ND \\
\hline 1588 & + & $114 \pm 27$ & ND & ND \\
\hline 1590 & + & $103 \pm 31$ & ND & ND \\
\hline $1593 a$ & + & $115 \pm 31$ & ND & ND \\
\hline $1593 b$ & + & $88 \pm 19$ & ND & ND \\
\hline 1615 & + & $118 \pm 34$ & ND & ND \\
\hline 1621 & + & $113 \pm 28$ & ND & $\mathrm{ND}$ \\
\hline $1624 a$ & + & $100 \pm 14$ & ND & ND \\
\hline $1624 b$ & + & $92 \pm 19$ & ND & ND \\
\hline 1634 & + & $115 \pm 61$ & ND & ND \\
\hline
\end{tabular}

${ }^{\mathrm{a}}$ For six to eight individual plants. Fixation activity was measured as the amount of $\mathrm{C}_{2} \mathrm{H}_{2}$ reduced per minute per g (dry weight) of nodule. ND $=$ not determined. 


\section{DISCUSSION}

Partial chromosome sequencing of the nitrogen-fixing $B$. japonicum led to the identification of potentially new genes involved in symbiosis. Genes coding for homologs of secreted plant cell wall-degrading enzymes were mutated to test their role in the invasion of root hair cells. None of the genes (gunA, gunA2, pgl, and pme), considered either individually or in combination, was critical for nodulation and nitrogen fixation in symbiosis. One explanation for this result might be the redundancy of genes for these enzymes, which could functionally replace each other and act in a network. These genes are clustered in relatively close vicinity within the symbiotic region, but even large deletions did not impair the symbiotic properties of the mutants. In the genome databases of Sinorhizobium meliloti, Mesorhizobium loti MAFF303099, and R7A, no homologs of gunA/A2, pgl, and pme of B. japonicum were found. No rhizobial genes coding for pectinolytic enzymes were reported in the literature, but cellulase activity was found in several rhizobial strains (Jimenez-Zurdo et al. 1996; Mateos et al. 1992, 2001) and also in B. japonicum 110spc4 (this study). Two genes coding for glycanases ( $p l y A$ and $p l y B$ ) have been sequenced so far in a symbiotic bacterium, and their products were not required to establish an effective symbiosis (Finnie et al. 1998). Furthermore, expression of a cellulase from the pathogenic organism E. carotovora in Rhizobium fredii did not influence nodulation of cowpea (Krishnan and Pueppke 1994). In addition, one cannot exclude the role of plant cell walldegrading enzymes produced by the host in the infection process. Legume plants excrete similar enzymes that could also be involved in symbiosis. A polygalacturonase was identified in the legume Medicago sativa that was specifically expressed in roots and nodules induced by $S$. melilot, but its role in symbiosis was not analyzed (Munoz et al. 1998). Although partial hydrolysis of the plant cell wall would seem to be a prerequisite for the penetration of the rhizobia into the root cells, such a mechanism is not yet proven.

In pathogenic bacteria, plant cell wall-degrading enzymes (pectinases, cellulases, proteases, phospholipases, and $\mathrm{xy}-$ lanases) act as virulence factors and enable the invasion of the host cell followed by its death (Barras et al. 1994; Collmer and Keen 1986). In the symbiotic relationship, the involvement of such enzymes would require a tight regulation of their activity so that it remains localized exclusively at the site of infection, in order to avoid destruction of the root hair.
Transcriptional lacZ fusions to gunA2, pgl, and pme were found to be weakly expressed in free-living cultures (10-fold above the $\beta$-galactosidase activity level of $B$. japonicum containing a promoterless $l a c Z$ gene), and gunA was not expressed at all in the tested conditions. Interestingly, expression of gunA2 and $p g l$ was strongly induced in medium containing genistein. Genistein and other flavonoids from host legumes are known to stimulate in rhizobia the synthesis of nodulation (nod) factors, which are involved in events prior to the infection of the root hairs (Göttfert 1993). In B. japonicum, nod gene transcription depends on the NodD or NodW transcription regulators, or both, which specifically bind to socalled nod-box regulatory sequences. In this context, it was interesting to note that expression of $g u n A 2$ and $p g l$ was abolished in $\operatorname{nod} W$ and $\operatorname{nod} D_{1+2}$ regulatory mutants, suggesting an involvement of these regulators in the control of gunA 2 and $p g l$; intriguingly, however, neither of the two putative target genes contained a possible promoter region with a nod-box consensus sequence. One possible explanation could be the existence of a hierarchical regulatory cascade in which NodW, NodD or both control a yet unidentified regulatory gene whose product, in turn, controls gunA2 and $\mathrm{pgl}$. An alternative type of flavonoid-dependent regulation not associated with nod boxes was already postulated in the transcriptional analysis of the symbiotic plasmid of Rhizobium sp. NGR234 (Perret et al. 1999).

Plant cell wall-degrading enzymes must be secreted by the bacteria to reach their site of action. By sequence analysis, peptide signals for secretion were detected in GunA, Pgl, and Pme, but not in GunA2, which does not necessarily imply that GunA2 is not secreted. In former studies, examples of isoflavone-inducible proteins that were secreted without N-terminal processing have been described in two species of rhizobia, NGR234 and S. fredii USDA257 (Krishnan 2002; Krishnan et al. 1995; Viprey et al. 1998). These proteins were exported via a type III secretion system that has recently been proven to play a role in specific symbioses (Marie et al. 2001). One should also mention here that the two glycanases of $R$. leguminosarum, PlyA and PlyB, do not possess any potential N-terminal secretion signals and are secreted via a type I secretion system (Finnie et al. 1998). However, they seemed to be activated by a bacterial expolysaccharide-related component (Zorreguieta et al. 2000). At present, the secretion pathway used for GunA2 remains speculative.

\begin{tabular}{|c|c|c|}
\hline ORF & RpoN binding site & NifA binding site \\
\hline$i d 117$ & TGGAAC- $\mathrm{N}_{5}$-TTGCT & TGT-N $_{10}-A C A(2 x)$ \\
\hline$i d 331$ & AGGCAT-N ${ }_{5}$-TTGCA & TGT-N ${ }_{10}-\mathrm{TCA}$ \\
\hline$i d 525$ & TGGCAC-N ${ }_{5}$-TTGCA & TGT-N ${ }_{10}-A C A$ \\
\hline$i d 747$ & TGGCAT- $\mathrm{N}_{5}$-TTGCT & CGT-N ${ }_{10}-A C A$ \\
\hline Consensus & TGGCAC-N ${ }_{5}-\mathrm{TTGC}^{\top} / \mathrm{A}$ & TGT-N ${ }_{10}-A C A$ \\
\hline
\end{tabular}

Fig. 4. Putative RpoN and NifA binding sites detected upstream of $i d 117, i d 331$, id525, and $i d 747$. Bold characters refer to the conserved nucleotides in the consensus sequence depicted in the last line. 
In the second part of this study, transcriptional lacZ fusions were used to investigate the regulation of four ORFs containing putative RpoN and NifA binding sites in the symbiotic region of $B$. japonicum. $\beta$-Galactosidase activity produced from $i d 117$, id525, and id747 was clearly induced in anaerobic conditions and was largely absent in both NifA- and RpoNdeficient backgrounds. This indicates that NifA is the activator of these genes whose transcription depends on the $\sigma^{54}$-RNA polymerase. By contrast, expression of a citA-like gene did not depend on RpoN and NifA, despite the presence of a -24/-12type consensus sequence containing only two mismatches in not absolutely conserved positions and a possible NifA-binding site with one mismatch at a conserved position. By comparison, the putative NifA binding site of $i d 747$, a gene that was shown to be controlled by NifA and RpoN (discussed above), had also one mismatch at a conserved position but only one mismatch at one less-conserved position in the RpoN consensus binding site. In conclusion, it is difficult to predict solely from sequence gazing whether or not a gene that carries these consensus sequences is actually subject to NifA and RpoN control. Interestingly, $i d 117$ has similarity to i) $m s i 158$ from $M$. loti R7A, which possesses a putative NifA binding site (Sullivan et al. 2002); ii) $y 4 m b$ from Rhizobium sp. NGR234, which is associated with a NifA/ $\sigma^{54}$-type promoter and is strongly expressed in nodules (Perret et al. 1999); and iii) omp21 from the soil bacterium Comamonas acidovorans, which is characterized by an enhanced expression in oxygen-depleted conditions (Baldermann et al. 1998).

The fact that NifA plays a crucial role in the symbiotic nitrogen fixation process as a key regulatory protein for many nif and fix genes initially led us to believe that any newly identified NifA target gene might also be involved in symbiosis. We now know that this assumption is not correct. The question regarding the potential function in symbiosis of id117, 525, and 747 was addressed by phenotypic analyses of appropriate mutants in a plant assay. The results clearly showed that these three NifA-controlled genes are not essential for nodulation and nitrogen fixation in symbiosis with soybean. It has been shown previously that the family of genes that are targets of NifA also includes anaerobically induced genes not directly related to nitrogen fixation, such as $g r o E S L_{3}$, hem $N_{1}, n d p, n r g A$, and $n r g B C$ (Fischer et al. 1993, 2001; Nienaber et al. 2000; Weidenhaupt et al. 1993). One could argue that both OMPs encoded by the $i d 117$ and $i d 525$ genes are redundant or are re-

Table 2. Aerobic and anaerobic expression ${ }^{\mathrm{a}}$

\begin{tabular}{|c|c|c|c|}
\hline \multirow[b]{2}{*}{ Strain } & \multirow[b]{2}{*}{ Relevant genotype } & \multicolumn{2}{|c|}{$\beta$-Galactosidase activity (Miller units) ${ }^{b}$} \\
\hline & & Aerobic growth ${ }^{c}$ & Anaerobic growth ${ }^{d}$ \\
\hline 1600 & citA-lacZ & $76.6 \pm 2.4$ & $53.2 \pm 2.8$ \\
\hline A1600 & citA-lacZ nifA & $72.8 \pm 2.6$ & $39.6 \pm 0.2$ \\
\hline N1600 & citA-lacZ $\operatorname{rpoN}_{1+2}$ & $76.7 \pm 3.8$ & $49.2 \pm 1.8$ \\
\hline 1613 & id747-lacZ & $25.5 \pm 3.9$ & $309.4 \pm 21.0$ \\
\hline A1613 & id747-lacZ nifA & $43.5 \pm 1.1$ & $20.8 \pm 3.4$ \\
\hline N1613 & id747-lacZ rpoN $N_{1+2}$ & $27.4 \pm 5.8$ & $34.1 \pm 2.4$ \\
\hline 1614 & id525-lacZ & $6.5 \pm 2.0$ & $893.6 \pm 92.8$ \\
\hline A1614 & id525-lacZ nifA & $9.0 \pm 2.3$ & $5.7 \pm 2.7$ \\
\hline N1614 & id525-lacZ rpoN $\mathrm{N}_{1+2}$ & $4.6 \pm 0.8$ & $9.3 \pm 1.6$ \\
\hline 1623 & id117-lacZ & $18.9 \pm 1.9$ & $596.9 \pm 77.3$ \\
\hline A1623 & id117-lacZ nifA & $18.3 \pm 0.9$ & $10.2 \pm 0.3$ \\
\hline N1623 & id117-lacZ rpoN $_{1+2}$ & $21.1 \pm 1.2$ & $13.9 \pm 1.5$ \\
\hline
\end{tabular}

${ }^{a}$ Expression of citA-, id117-, id525-, id747-lacZ fusions chromosomally integrated in different Bradyrhizobium japonicum strains.

${ }^{\mathrm{b}}$ Numbers are mean values \pm standard errors of four independent cultures of individual strains, which were assayed in duplicate.

c Aerobic cultures were grown for $48 \mathrm{~h}$ in peptone-salts-yeast extract medium.

${ }^{\mathrm{d}}$ Anaerobic cultures were grown for 4 to 5 days in yeast extract-mannitol medium containing $10 \mathrm{mM} \mathrm{KNO}_{3}$. placed by potential homologs in the respective mutants. However, the amino acid sequences of proteins Id117 and Id525 do not share any similarity. Southern blot hybridization experiments under low-stringency conditions with a suitable id117 probe did not reveal any additional bands (data not shown), whereas id525 does share some similarity with id352, id693, and $i d 877$, which are also localized in the symbiotic gene region (Göttfert et al. 2001). However, two of these homologs (id352 and id693) do not possess putative NifA and RpoN binding sites, suggesting a different kind of regulation for these genes. Gene id747 shared no similarity with known sequences in the databases and was dispensable in symbiosis; therefore, its function and the nature of the gene product remain unclear.

Regarding the role of citA, a gene that is also not essential for symbiosis and that was shown not to be controlled by NifA and RpoN, there is evidence to suggest the existence of additional citrate uptake systems, because the citA mutant was still able to grow on citrate as the sole carbon source; yet, no closely related gene was detected by Southern blot hybridization of restricted chromosomal DNA using citA as a probe (data not shown).

In conclusion, the question of whether or not plant cell walldegrading enzymes of bacterial origin function in symbiosis between B. japonicum and its host plants (soybean, cowpea, and mung bean) could not be answered. Nevertheless, this study has identified one genuine cellulase (GunA2) and one putative polygalacturonase $(\mathrm{Pgl})$ induced by the flavonoid genistein, a compound that is known to be an important nod gene inducer in the early events of the symbiotic process. Sequence analysis of the symbiotic region has revealed three potential NifA- or RpoN-regulated genes, whose expression was indeed dependent on these regulators and a low-oxygen status of the cell, but they did not correlate with a function in symbiosis. Thus, the family of NifA-regulated genes that are symbiotically irrelevant has grown by three members.

\section{MATERIALS AND METHODS}

Bacterial strains, plasmids, media, and growth conditions.

The bacterial strains and plasmids used in this work are listed in Table 3. Luria-Bertani (LB) medium was used for growth of Escherichia coli and E. carotovora. When appropriate, antibiotics were used at the following concentrations ( $\mu \mathrm{g}$ per ml): kanamycin, 30; tetracycline, 10; and ampicillin, 200. PSY medium (Regensburger and Hennecke 1983) supplemented with $0.1 \%$ L-arabinose was used for aerobic cultures of B. japonicum, whereas yeast extract-mannitol medium (Daniel and Appleby 1972) supplemented with $10 \mathrm{mM} \mathrm{KNO}_{3}$ was used for anaerobic B. japonicum cultures. Anaerobic cultures were kept under argon in rubber-stoppered serum bottles. The following concentrations of antibiotics were used for B. japonicum cultures ( $\mu \mathrm{g}$ per ml): spectinomycin, 100; kanamycin, 100; tetracycline, 50 (solid media) or 25 (liquid media); streptomycin, 50; and gentamicin, 150.

\section{DNA work and sequence analysis.}

Recombinant DNA work and Southern blotting were performed according to standard protocols (Sambrook and Russel 2001). Digoxigenin-labeled DNA probes generated by PCR were used for Southern hybridization (DIG DNA labeling kit; Roche Diagnostics, Rotkreuz, Switzerland). B. japonicum chromosomal DNA was isolated as described (Hahn and Hennecke 1984). For computer-assisted analyses of DNA and protein sequences, we used the software package (version 10.0) of the Genetics Computer Group (University of Wisconsin, Madison, WI, U.S.A.). Homology searches were performed using the National Center for Biotechnology Information BLAST network server. 
Construction of chromosomally integrated lacZ fusions.

To construct transcriptional lacZ fusions to the gunA, gunA2, pgl, pme, id117, citA, id525, and id747 genes, fragments of approximately $500 \mathrm{bp}$ of the noncoding $5^{\prime}$ end of each gene were ligated to the appropriate linearized vector pRJ5631 containing a promoterless lac $Z$ gene and a ribosome binding site preceded by three stop codons. The oligonucleotide sequences used to amplify the fragments are available from the authors on request. The correct sequence of all inserts was confirmed by sequencing. These constructs were mobilized into the $B$. japonicum wild type (strain 110spc4) and into suitable regulatory mutants (Table 3 and Fig. 1). The correct genomic integration was verified by colony PCR or Southern blot hybridization.

\section{Construction of gunA,}

gunA2, pgl, pme, citA, id117, id525, and id747 mutants.

Insertion-inactivation mutagenesis of gunA, pgl, pme, citA, and $i d 747$ genes was achieved by subcloning internal fragments of the target genes into the vector pSUP202pol4, which cannot replicate in B. japonicum. These constructs were integrated into the $B$. japonicum $110 \mathrm{spc} 4$ chromosome by conjugation, resulting in the mutant strains 1570,1572 , 1574, 1590, and 1615 (Fig. 1 and Table 3). Conjugants carrying plasmid insertions were selected on tetracycline-contain- ing plates. The gunA2 gene was mutagenized by insertion of a 1.2-kb SacI kanamycin-resistance cassette (aphII), isolated from pBSL15 (Alexeyev 1995) into its unique SacI site. The id117 gene was mutated by deleting a $0.527-\mathrm{kb}$ SacI fragment that was replaced by a SacI aphII cassette. Similarly, the id525 gene was mutated by deleting a 1.4-kb PstI fragment, replacing it with a PstI aphII cassette. Appropriate DNA fragments containing the region to be mutated were cloned into the vector pSUP202pol4 and were mobilized into B. japonicum $110 s p c 4$ by conjugation, resulting in the mutant strains 1585, 1634, and 1624 (Table 3). For construction of the double-mutant gunA-gunA2 (strain 1585+1574), the plasmid pRJ1574, containing an internal fragment of gunA, was integrated by homologous recombination into the chromosome of mutant strain 1585 . To construct $B$. japonicum $1585+1622$, the $p g l$ and pme genes were mutagenized by deleting a $1.8-\mathrm{kb} A p a \mathrm{I} / \mathrm{XhoI}$ fragment, replacing it with a $1.6-\mathrm{kb}$ ApaI/XhoI gentamicin cassette isolated from pBSL142 (Alexeyev et al. 1995). The DNA fragment containing the mutated pgl and pme was cloned into pSUP202pol4 and was mobilized into B. japonicum 1585 (Fig. 1). The strategy used to construct deletion mutants 1588,1593 , and 1621 of $B$. japonicum was as follows: two approximately $1.5-\mathrm{kb}$ DNA fragments flanking the aphII cassette from pBSL15 were

Table 3. Bacterial strains and plasmids used in this work

\begin{tabular}{|c|c|c|}
\hline Strain & Relevant genotype or phenotype & Source or reference \\
\hline \multicolumn{3}{|l|}{ Escherichia coli } \\
\hline DH5 $\alpha$ & supE44AlacU169 ( $\psi 80 l a c Z 4 M 15)$ hsdR1 recA1 gyrA96 thi-1 relA1 & BRL, Gaithersburg, U.S.A. \\
\hline S17-1 & $\mathrm{Sm}^{\mathrm{r}} \mathrm{Sp}^{\mathrm{r}}$ hdsR (RP4-2 kan::Tn7 tet::Mu integrated in the chromosome) & Simon et al. 1983 \\
\hline BL21 (DE3) & $\mathrm{Cm}^{\mathrm{r}} \mathrm{F}^{-}$ompT lon hsd $S_{\mathrm{B}}\left(\mathrm{r}_{\mathrm{B}}^{-}{ }^{-}\right.$gal dcm (DE3); T7-RNA polymerase gene with lacUV5-promoter & Studier et al. 1986 \\
\hline \multicolumn{3}{|c|}{ Bradyrhizobium japonicum } \\
\hline $110 \operatorname{spc} 4$ & $\mathrm{Sp}^{\mathrm{r}}$, wild type & Regensburger and Hennecke 1983 \\
\hline 613 & $\mathrm{Sp}^{\mathrm{r}} \mathrm{Sm}^{\mathrm{r}} \operatorname{nod} W:: \Omega$ & Göttfert et al. 1990a \\
\hline$\Delta 1267$ & $\mathrm{Sp}^{\mathrm{r}} \mathrm{Km}^{\mathrm{r}} \Delta(\operatorname{nodD} 1-\operatorname{nod} D 2):: a p h I I$ & Göttfert et al. 1992 \\
\hline A9 & $\mathrm{Sp}^{\mathrm{r}} \mathrm{Km}^{\mathrm{r}}$ nifA::aphII & Fischer et al. 1986 \\
\hline N50-97 & $\mathrm{Sp}^{\mathrm{r}} \mathrm{Km}^{\mathrm{r}} \mathrm{Sm}^{\mathrm{r}} \operatorname{rpoN}_{1}::$ aphII rpoN $N_{2}:: \Omega$ & Kullik et al. 1991 \\
\hline 1570 & $\mathrm{Sp}^{\mathrm{r}} \mathrm{Tc}^{\mathrm{r}}$ pme::pSUP202pol4 & This work \\
\hline 1572 & $\mathrm{Sp}^{\mathrm{r}} \mathrm{Tc}^{\mathrm{r}}$ pgl::pSUP202pol4 & This work \\
\hline 1574 & $\mathrm{Sp}^{\mathrm{r}} \mathrm{Tc}^{\mathrm{r}}$ gunA::pSUP202pol4 & This work \\
\hline 1585 & $\mathrm{Sp}^{\mathrm{r}} \mathrm{Km}^{\mathrm{r}}$ gunA2::aphII (in the opposite orientation) & This work \\
\hline $1585+1574$ & $\mathrm{Sp}^{\mathrm{r}} \mathrm{Tc}^{\mathrm{r}} \mathrm{Km}^{\mathrm{r}}$ gunA::pSUP202pol4, gunA2::aphII & This work \\
\hline $1585+1622$ & $\mathrm{Sp}^{\mathrm{r}} \mathrm{Km}^{\mathrm{r}} \mathrm{Gm}^{\mathrm{r}}$ gunA2::aphII, pgl-pme::genA & This work \\
\hline 1588 & $\mathrm{Sp}^{\mathrm{r}} \mathrm{Km}^{\mathrm{r}} \Delta($ id549-id585)::aphII & This work \\
\hline 1589 & $\mathrm{Sp}^{\mathrm{r}} \mathrm{Tc}^{\mathrm{r}}$ gunA-lacZ chromosomally integrated & This work \\
\hline 1590 & $\mathrm{Sp}^{\mathrm{r}} \mathrm{Tc}^{\mathrm{r}}$ citA::pSUP202pol4 & This work \\
\hline $1593(\mathrm{a}+\mathrm{b})$ & $\mathrm{Sp}^{\mathrm{r}} \mathrm{Km}^{\mathrm{r}} \Delta($ id588-id606)::aphII (both orientations; a: same orientation; b: opposite orientation) & This work \\
\hline $1599^{\mathrm{a}}$ & $\mathrm{Sp}^{\mathrm{r}} \mathrm{Tc}^{\mathrm{r}}$ gunA2-lacZ chromosomally integrated & This work \\
\hline $1600^{\mathrm{b}}$ & $\mathrm{Sp}^{\mathrm{r}} \mathrm{Tc}^{\mathrm{r}}$ citA-lac $Z$ chromosomally integrated & This work \\
\hline $1612^{\mathrm{a}}$ & $\mathrm{Sp}^{\mathrm{r}} \mathrm{Tc}^{\mathrm{r}}$ pgl-lacZ chromosomally integrated & This work \\
\hline $1613^{\mathrm{b}}$ & $\mathrm{Sp}^{\mathrm{r}} \mathrm{Tc}^{\mathrm{r}}$ id747-lacZ chromosomally integrated & This work \\
\hline $1614^{\mathrm{b}}$ & $\mathrm{Sp}^{\mathrm{r}} \mathrm{Tc}^{\mathrm{r}}$ id525-lacZ chromosomally integrated & This work \\
\hline 1615 & $\mathrm{Sp}^{\mathrm{r}} \mathrm{Tc}^{\mathrm{r}} i d 747:: \mathrm{pSUP} 202$ pol4 & This work \\
\hline 1617 & $\mathrm{Sp}^{\mathrm{r}} \mathrm{Tc}^{\mathrm{r}}$ pme-lacZ chromosomally integrated & This work \\
\hline 1621 & $\mathrm{Sp}^{\mathrm{r}} \mathrm{Km}^{\mathrm{r}} \Delta($ id619-id637)::aphII & This work \\
\hline $1623^{\mathrm{b}}$ & $\mathrm{Sp}^{\mathrm{r}} \mathrm{Tc}^{\mathrm{r}}$ id117-lac Z chromosomally integrated & This work \\
\hline $1624(\mathrm{a}+\mathrm{b})$ & $\mathrm{Sp}^{\mathrm{r}} \mathrm{Km}^{\mathrm{r}}$ id525::aphII (both orientations; a: same orientation, b: opposite orientation) & This work \\
\hline 1634 & $\mathrm{Sp}^{\mathrm{r}} \mathrm{Km}^{\mathrm{r}}$ id117::aphII (in the same orientation) & This work \\
\hline \multicolumn{2}{|c|}{ Erwinia carotovora subsp. carotovora } & DSMZ; Germany \\
\hline \multicolumn{3}{|l|}{ Plasmids } \\
\hline pET24b & $\mathrm{Km}^{\mathrm{r}}$ & Novagen \\
\hline pBSL15 & $\mathrm{Ap}^{\mathrm{r}} \mathrm{Km}^{\mathrm{r}}$ & Alexeyev 1995 \\
\hline pBSL142 & $\mathrm{Gm}^{\mathrm{r}}$ & Alexeyev et al. 1995 \\
\hline pSUP202pol4 & $\mathrm{Tc}^{\mathrm{r}}$ (pSUP202) part of polylinker from pBluescript II KS+ between EcoRI and PstI & Fischer et al. 1993 \\
\hline pRJ5631 & $\mathrm{Tc}^{\mathrm{r}}(\mathrm{pSUP} 202 \mathrm{pol} 4)$ lac Z & From this laboratory \\
\hline pRJ1605 & $\mathrm{Kmr}$ (pET24b) gunA (coding sequence of gunA without the leader peptide-coding region) & This work \\
\hline pRJ1606 & $\mathrm{Kmr}(\mathrm{pET} 24 \mathrm{~b})$ gunA2 & This work \\
\hline
\end{tabular}

a The gunA2-lacZ was also integrated into the chromosome of B. japonicum 613 and $\Delta 1267$. The pgl-lacZ was integrated exclusively into the chromosome of $B$. japonicum 613 . The resulting strains were given the same numbers 1599 or 1612 preceded by $\mathrm{W}(613$ derivative) or D ( $\Delta 1267$ derivative).

b The citA-lacZ, id117-lacZ, id525-lacZ, and id747-lacZ were also integrated into the chromosome of B. japonicum A9 and N50-97. The resulting strains were given the same numbers preceded by A (A9 derivative) or $\mathrm{N}$ (N50-97 derivative). 
cloned into the vector pSUP202pol4. These constructs were integrated into the $B$. japonicum wild-type $110 s p c 4$ chromosome by double crossing-over (Fig. 1 and Table 3 ). The chromosomal regions comprising nucleotide positions 60,153 to 70,059 in the mutant 1588 , from nuleotide 71,558 to 80,229 in strain1621, and from nucleotide 81,631 to 94,489 in strain 1593 (nucleotide position numbers refer to the EMBL database entry under accession number AF322013) were deleted. The correct genomic structures of all mutants were confirmed by colony PCR or Southern blot hybridization.

\section{$\beta$-Galactosidase assays.}

$\beta$-Galactosidase activity assays were performed as described previously (Fischer et al. 1993).

\section{GunA and GunA2 expression and purification.}

Plasmids pRJ1605 and pRJ1606 were constructed for the production of GunA and GunA2 by respective cloning of the corresponding genes into the $\mathrm{NdeI}$ and $\mathrm{XhoI}$ sites and the NdeI and NotI sites of expression vector pET24b (Novagen, Schwalbach, Germany). Cellulases were expressed in the host strain Escherichia coli BL21(DE3)pLysS. Overexpression cultures were grown at $37^{\circ} \mathrm{C}$. Once they reached an optical density at $600 \mathrm{~nm}$ of 0.6 , production of the recombinant proteins was induced by addition of $0.5 \mathrm{mM}$ IPTG. After $3 \mathrm{~h}$ of induction, bacterial cells were harvested, were resuspended in binding buffer (20 mM Tris- $\mathrm{HCl}, \mathrm{pH} 7.9,500 \mathrm{mM} \mathrm{NaCl}, 5 \mathrm{mM}$ imidazole), and were frozen at $-30^{\circ} \mathrm{C}$. Lysis was performed by cell thawing and sonication for $15 \mathrm{~min}$. Soluble crude extracts were prepared by centrifugation at $15,000 \mathrm{~g}$ for $30 \mathrm{~min}$ at $4{ }^{\circ} \mathrm{C}$. The supernatant was cleared by ultracentrifugation at $45,000 \mathrm{~g}$ for $60 \mathrm{~min}$ at $4^{\circ} \mathrm{C}$. Purification of hexahistidine-tagged proteins was performed by Ni-NTA affinity chromatography under native conditions with Ni-NTA resin from Qiagen (Basel, Switzerland). The column was equilibrated with binding buffer. After application of the crude extract, the column was washed with a solution of $25 \mathrm{mM}$ imidazole and, subsequently, with a solution of $30 \mathrm{mM}$ imidazole. Proteins were eluted in 2 steps, first with $150 \mathrm{mM}$ imidazole and, thereafter, with 300 mM imidazole.

\section{Cellulase activity in vivo and in vitro.}

For plate assays, bacteria were directly streaked on PSY plates containing $0.1 \% \mathrm{CMC}$. After seven days of growth at $30^{\circ} \mathrm{C}$, plates were stained with $0.1 \%$ Congo Red for $30 \mathrm{~min}$ and were rinsed with $1 \mathrm{M} \mathrm{NaCl}$ for 30 min (Teather and Wood 1982). For quantitative enzyme assays, the reaction mixture containing $0.4 \mathrm{ml}$ of substrate $(2 \% \mathrm{CMC}$ in $50 \mathrm{mM}$ citrate buffer, $\mathrm{pH} 4.8$ ) and $0.4 \mathrm{ml}$ of recombinant enzyme (in $50 \mathrm{mM}$ citrate buffer, $\mathrm{pH}$ 4.8). A 0.4-ml sample (considered as $t=0 \mathrm{~h}$ ) was frozen at $-80^{\circ} \mathrm{C}$. The rest of the sample was incubated at $30^{\circ} \mathrm{C}$ overnight. Product formation was measured by using the 2,2'-bicinchoninate method (Waffenschmidt et al. 1987). Samples were mixed with $0.1 \mathrm{ml}$ of water and $0.5 \mathrm{ml}$ of 2,2'-bicinchoninate reagent and were heated at $100^{\circ} \mathrm{C}$ for $15 \mathrm{~min}$. Their optical density was measured at $540 \mathrm{~nm}$. A standard curve for reducing sugars was prepared with glucose in the range of 0 to $50 \mathrm{nmol}$. Commercially available cellulase from Aspergillus niger (Sigma, Buchs, Switzerland) was used as a positive control.

\section{Plant infection test.}

The symbiotic phenotype of the knock-out mutants was determined in plant infection tests using soybean, cowpea, and mung bean as host plants, and nitrogenase activity was measured in an acetylene reduction assay (Göttfert et al. 1990b; Hahn and Hennecke 1984).

\section{ACKNOWLEDGMENTS}

This work was supported by a grant from the Swiss National Foundation for Scientific Research. We thank Z. Ucurum for expert technical assistance and H.-M. Fischer for strains and valuable suggestions.

\section{LITERATURE CITED}

Alexeyev, M. F. 1995. Three kanamycin resistance gene cassettes with different polylinkers. Biotechniques 18:52-54.

Alexeyev, M. F., Shokolenko, I. N., and Croughan, T. P. 1995. Improved antibiotic-resistance gene cassettes and omega elements for Escherichia coli vector construction and in vitro deletion/insertion mutagenesis. Gene 160:63-67.

Baldermann, C., Lupas, A., Lubieniecki, J., and Engelhardt, H. 1998. The regulated outer membrane protein Omp21 from Comamonas acidovorans is identified as a member of a new family of eight-stranded beta-sheet proteins by its sequence and properties. J. Bacteriol. 180:3741-3749.

Barras, F., van Gijsegem, F., and Chatterjee, A. K. 1994. Extracellular enzymes and pathogenesis of soft-rot Erwinia. Annu. Rev. Phytopathol. 32:201-234.

Bauer, E., Kaspar, T., Fischer, H. M., and Hennecke, H. 1998. Expression of the fixR-nifA operon in Bradyrhizobium japonicum depends on a new response regulator, RegR. J. Bacteriol. 180:3853-3863.

Collmer, A., and Keen, N. T. 1986. The role of pectic enzymes in plant pathogenesis. Annu. Rev. Phytopathol. 24:383-409.

Daniel, R. M., and Appleby, C. A. 1972. Anaerobic-nitrate, symbiotic and aerobic growth of Rhizobium japonicum: effects on cytochrome P450, other haemoproteins, nitrate and nitrite reductases. Biochem. Biophys. Acta. 275:347-354.

Finnie, C., Hartley, N. M., Findlay, K. C., and Downie, J. A. 1997. The Rhizobium leguminosarum prsDE genes are required for secretion of several proteins, some of which influence nodulation, symbiotic nitrogen fixation and exopolysaccharide modification. Mol. Microbiol. 25:135-146.

Finnie, C., Zorreguieta, A., Hartley, N. M., and Downie, J. A. 1998. Characterization of Rhizobium leguminosarum exopolysaccharide glycanases that are secreted via a type I exporter and have a novel heptapeptide repeat motif. J. Bacteriol. 180:1691-1699.

Fischer, H. M. 1994. Genetic regulation of nitrogen fixation in rhizobia. Microbiol. Rev. 58:352-386.

Fischer, H. M. 1996. Environmental regulation of rhizobial symbiotic nitrogen fixation genes. Trends Microbiol. 4:317-320.

Fischer, H. M., Alvarez-Morales, A., and Hennecke, H. 1986. The pleiotropic nature of symbiotic regulatory mutants: Bradyrhizobium japonicum nifA gene is involved in control of nif gene expression and formation of determinate symbiosis. EMBO (Eur. Mol. Biol. Organ.) J. 5:1165-1173.

Fischer, H. M., Babst, M., Kaspar, T., Acuña, G., Arigoni, F., and Hennecke, H. 1993. One member of a groESL-like chaperonin multigene family in Bradyrhizobium japonicum is co-regulated with symbiotic nitrogen fixation genes. EMBO (Eur. Mol. Biol. Organ.) J. 12:2901-2912.

Fischer, H. M., Velasco, L., Delgado, M. J., Bedmar, E. J., Schären, S., Zingg, D., Göttfert, M., and Hennecke, H. 2001. One of two hemN genes in Bradyrhizobium japonicum is functional during anaerobic growth and in symbiosis. J. Bacteriol. 183:1300-1311.

Göttfert, M. 1993. Regulation and function of rhizobial nodulation genes. FEMS (Fed. Eur. Microbiol. Soc.) Microbiol. Rev. 104:39-64.

Göttfert, M., Grob, P., and Hennecke, H. 1990a. Proposed regulatory pathway encoded by the nodV and nod $W$ genes, determinants of host specificity in Bradyrhizobium japonicum. Proc. Natl. Acad. Sci. U.S.A. 87:2680-2684.

Göttfert, M., Hitz, S., and Hennecke, H. 1990b. Identification of nodS and nod $U$, two inducible genes inserted between the Bradyrhizobium japonicum nodYABC and nodIJ genes. Mol. Plant-Microbe Interact. 3:308-316.

Göttfert, M., Holzhäuser, D., Bäni, D., and Hennecke, H. 1992. Structural and functional analysis of two different nodD genes in Bradyrhizobium japonicum USDA110. Mol. Plant-Microbe Interact. 5:257-265.

Göttfert, M., Röthlisberger, S., Kündig, C., Beck, C., Marty, R., and Hennecke, H. 2001. Potential symbiosis-specific genes uncovered by sequencing a 410-kilobase DNA region of the Bradyrhizobium japonicum chromosome. J. Bacteriol. 183:1405-1412.

Hahn, H., and Hennecke, H. 1984. Localized mutagenesis in Rhizobium japonicum. Mol. Gen. Genet. 193:46-52.

Henrissat, B., and Bairoch, A. 1993. New families in the classification of glycosyl hydrolases based on amino acid sequence similarities. Biochem. J. 293:781-788. 
Jimenez-Zurdo, J. I., Mateos, P. F., Dazzo, F. B., and Martinez-Molina, E. 1996. Cell-bound cellulase and polygalacturonase production by Rhizobium and Bradyrhizobium species. Soil. Biol. Biochem. 28:917921

Krishnan, H. B. 2002. NolX of Sinorhizobium fredii USDA257, a type III-secreted protein involved in host range determination, is localized in the infection threads of cowpea (Vigna unguiculata [L.] Walp) and soybean (Glycine max [L.] Merr.) nodules. J. Bacteriol. 184:831-839.

Krishnan, H. B., and Pueppke, S. G. 1994. A cloned cellulase gene from Erwinia carotovora subsp. carotovora is expressed in Rhizobium fredil but does not influence nodulation of cowpea. FEMS (Fed. Eur. Microbiol. Soc.) Microbiol. Lett. 119:289-294.

Krishnan, H. B., Kuo, C., and Pueppke, S. G. 1995. Elaboration of flavonoid-induced proteins by the nitrogen-fixing soybean symbiont Rhizobium fredii is regulated by both nodD1 and nodD2, and is dependent on the cultivar-specificity locus, nolXWBUTV. Microbiology 141:2245-2251

Kullik, I., Fritsche, S., Knobel, H., Sanjuan, J., Hennecke, H., and Fischer, H. M. 1991. Bradyrhizobium japonicum has two differentially regulated, functional homologs of the sigma 54 gene $(r p o N)$. J. Bacteriol. 173:1125-1138.

Kündig, C., Hennecke, H., and Göttfert, M. 1993. Correlated physical and genetic map of the Bradyrhizobium japonicum 110 genome. J. Bacteriol. 175:613-622.

Mae, A., Heikinheimo, R., and Palva, E. T. 1995. Structure and regulation of the Erwinia carotovora subspecies carotovora SCC3193 cellulase gene celV1 and the role of cellulase in phytopathogenicity. Mol. Gen. Genet. 247:17-26.

Marie, C., Broughton, W. J., and Deakin, W. J. 2001. Rhizobium type III secretion systems: legume charmers or alarmers? Curr. Opin. Plant. Biol. 4:336-342.

Marits, R., Koiv, V., Laasi, E., and Mae, A. 1999. Isolation of an extracellular protease gene of Erwinia carotovora subsp. carotovora strain SCC3193 by transposon mutagenesis and the role of protease in phytopathogenicity. Microbiology 145:1959-1966.

Mateos, P. F., Jimenez-Zurdo, J. I., Chen, J., Squartini, A. S., Haack, S. K., Martinez-Molina, E., Hubbell, D. H., and Dazzo, F. B. 1992. Cellassociated pectinolytic and cellulolytic enzymes in Rhizobium leguminosarum biovar trifolii. Appl. Environ. Microbiol. 58:1816-1822.

Mateos, P. F., Baker, D. L., Petersen, M., Velazquez, E., Jimenez-Zurdo, J. I., Martinez-Molina, E., Squartini, A., Orgambide, G., Hubbell, D. H., and Dazzo, F. B. 2001. Erosion of root epidermal cell walls by Rhizobium polysaccharide-degrading enzymes as related to primary host infection in the Rhizobium- legume symbiosis. Can. J. Microbiol. 47:475-487.

Munoz, J. A., Coronado, C., Perez-Hormaeche, J., Kondorosi, A., Ratet, P., and Palomares, A. J. 1998. MsPG3, a Medicago sativa polygalacturonase gene expressed during the alfalfa-Rhizobium meliloti interaction. Proc. Natl. Acad. Sci. U.S.A. 95:9687-9692.

Nienaber, A., Huber, A., Göttfert, M., Hennecke, H., and Fischer, H. M. 2000. Three new NifA-regulated genes in the Bradyrhizobium japonicum symbiotic gene region discovered by competitive DNA-RNA hybridization. J. Bacteriol. 182:1472-1480.

Perret, X., Freiberg, C., Rosenthal, A., Broughton, W. J., and Fellay, R. 1999. High-resolution transcriptional analysis of the symbiotic plasmid of Rhizobium sp. NGR234. Mol. Microbiol. 32:415-425.

Regensburger, B., and Hennecke, H. 1983. RNA polymerase from Rhizobium japonicum. Arch. Microbiol. 135:103-109.

Roberts, D. P., Denny, T. P., and Schell, M. A. 1988. Cloning of the egl gene of Pseudomonas solanacearum and analysis of its role in phytopathogenicity. J. Bacteriol. 170:1445-1451.

Saarilahti, H. T., Heino, P., Pakkanen, R., Kalkkinen, N., Palva, I., and Palva, E. T. 1990a. Structural analysis of the pehA gene and characterization of its protein product, endopolygalacturonase, of Erwinia carotovora subspecies carotovora. Mol. Microbiol. 4:1037-1044.
Saarilahti, H. T., Henrissat, B., and Palva, E. T. 1990b. CelS: A novel endoglucanase identified from Erwinia carotovora subsp. carotovora. Gene 90:9-14.

Saarilahti, H. T., Pirhonen, M., Karlsson, M. B., Flego, D., and Palva, E. T. 1992. Expression of pehA-bla gene fusions in Erwinia carotovora subsp. carotovora and isolation of regulatory mutants affecting polygalacturonase production. Mol. Gen. Genet. 234:81-88.

Sambrook, J., and Russel, D. W. 2001. Molecular Cloning: A Laboratory Manual. Cold Spring Harbor Laboratory Press. Cold Spring Harbor, NY, U. S. A.

Schell, M. A., Roberts, D. P., and Denny, T. P. 1988. Analysis of the Pseudomonas solanacearum polygalacturonase encoded by $\mathrm{pglA}$ and its involvement in phytopathogenicity. J. Bacteriol. 170:4501-4508.

Shevchik, V. E., Condemine, G., Hugouvieux-Cotte-Pattat, N., and Robert-Baudouy, J. 1996. Characterization of pectin methylesterase B, an outer membrane lipoprotein of Erwinia chrysanthemi 3937. Mol. Microbiol. 19:455-466.

Shevchik, V. E., and Hugouvieux-Cotte-Pattat, N. 1997. Identification of a bacterial pectin acetyl esterase in Erwinia chrysanthemi 3937. Mol. Microbiol. 24:1285-1301.

Simon, R., Priefer, U., and Pühler, A. 1983. Vector plasmids for in vivo and in vitro manipulation of gram-negative bacteria. Pages 98-106 in: Molecular Genetics of the Bacteria-Plant Interaction. A. Pühler, ed Springer Verlag, Heidelberg, Germany.

Studier, F. W., and Moffatt, B. A. 1986. Use of bacteriophage T7 RNA polymerase to direct selective high-level expression of cloned genes. J. Mol. Biol. 189:113-130.

Sullivan, J. T., Trzebiatowski, J. R., Cruickshank, R. W., Gouzy, J., Brown, S. D., Elliot, R. M., Fleetwood, D. J., McCallum, N. G., Rossbach, U., Stuart, G. S., Weaver, J. E., Webby, R. J., de Bruijn, F. J., and Ronson, C. W. 2002. Comparative sequence analysis of the symbiosis island of Mesorhizobium loti R7A. J. Bacteriol. 184:30863095.

Tans-Kersten, J., Guan, Y., and Allen, C. 1998. Ralstonia solanacearum pectin methylesterase is required for growth on methylated pectin but not for bacterial wilt virulence. Appl. Environ. Microbiol. 64:4918 4923

Teather, R. M., and Wood, P. J. 1982. Use of Congo red-polysaccharide interactions in enumeration and characterization of cellulolytic bacteria from the bovine rumen. Appl. Environ. Microbiol. 43:777-780.

Viprey, V., Del Greco, A., Golinowski, W., Broughton, W. J., and Perret, X. 1998. Symbiotic implications of type III protein secretion machinery in Rhizobium. Mol. Microbiol. 28:1381-1389.

Waffenschmidt, S., and Jaenicke, L. 1987. Assay of reducing sugars in the nanomole range with 2,2'-bicinchoninate. Anal. Biochem. 165:337-340.

Weidenhaupt, M., Fischer, H. M., Acuña, G., Sanjuan, J., and Hennecke, H. 1993. Use of a promoter-probe vector system in the cloning of a new NifA-dependent promoter ( $n d p)$ from Bradyrhizobium japonicum. Gene 129:33-40.

Zorreguieta, A., Finnie, C., and Downie, J. A. 2000. Extracellular glycanases of Rhizobium leguminosarum are activated on the cell surface by an exopolysaccharide-related component. J. Bacteriol. 182:1304-1312.

\section{AUTHOR-RECOMMENDED INTERNET RESOURCES}

INRA genome sequencing project database for Sinorhizobium meliloti: sequence.toulouse.inra.fr/meliloti.html.

INRA genome sequencing project database for R7A: sequence.toulouse.inra.fr/msi

Kazusa DNA Research Institute genome database for rhizobia (for Mesorhizobium loti MAFF303099): www.kazusa.or.jp/rhizobase.

National Center for Biotechnology Information BLAST network server: www.ncbi.nlm.nih.gov/BLAST. 